\title{
СТАТИСТИКА КРЕЩЕНИЙ В ПРАВОСЛАВИЕ ВО ВЛАДИМИРСКОЙ ГУБЕРНИИ В КОНЦЕ ХІХ - НАЧАЛЕ ХХ ВЕКА
}

\author{
Кувенева В.О. \\ Учёный секретарь Ивановского отделения \\ ВОО «Русское географическое общество»
}

\section{STATISTICS OF BAPTISMS TO ORTHODOXY IN THE VLADIMIR PROVINCE IN THE LATE XIX-EARLY XX CENTURY}

Kuveneva $V . O$.

Scientific Secretary Ivanovo regional branch of the Russian Geographical Society

\begin{abstract}
Аннотация. В статье приводятся данные исследования статистических материалов, публиковавшихся в периодическом издании «Владимирские епархиальные ведомости» в период с 1889 по 1905 годы. Статья затрагивает историю развития внутренней миссии Владимирской губернии в цифровых данных. Приводится статистика крещений в православие по годам, классификация принявших крещение по различным признакам. Также даются общие цифры численности миссионеров в губернии и принявших православие.

Annotation. The article presents the data of the study of statistical materials published in the periodical "Vladimir Diocesan Gazette" in the period from 1889 to 1905. The article touches on the history of the development of the internal mission of the Vladimir province in digital data. The statistics of baptisms in Orthodoxy by year, the classification of those who were baptized on various grounds are given. The general figures of the number of missionaries in the province and those who converted to Orthodoxy are also given.
\end{abstract}

Ключевые слова: Владимирские епархиальные ведомости, Владимирская губерния, статистические таблицы, миссионерство, внутренняя миссия.

Key words: Vladimir Diocesan Gazette, Vladimir province, statistical tables, missionary work, internal mission.

Изначально миссионерство было одной из основополагающих форм деятельности в христианстве. Русская Православная Церковь переняла этот опыт служения и во второй половине XIX века подняла до мировых размеров (американская, китайская, корейская и японская православные миссии).

В статье мы остановимся на внутренней миссии Владимирской губернии конца XIX - начала XX века. Во Владимирской губернии доля раскольничьего населения по отношению к другим религиозным течениям (кроме православия) была самой большой, поэтому миссионеры в первую очередь готовились к духовно-нравственной и просветительской деятельности в этой среде. Крещение в православие из других конфессий было редким событием и связывалось, в основном, с личными убеждениями крещаемых, влиянием на них окружения или другими обстоятельствами.

Итак, миссионерство - это деятельность представителей религиозных организаций, направленная на распространение своего вероисповедания среди неверующих или инаковерующих [3, с. 237].

В конце XIX века магистр богословия Иван Преображенский отметил, что увидеть масштабы миссионерской деятельности в пределах десятилетий достаточно сложно. Если брать за мерку каждые пятьдесят, двадцать пять, десять лет, то, вероятнее всего, никакой разницы не будет. Но, если рассматривать каждый год в отдельности и потом суммировать, подводя итоги, можно увидеть, как разнятся данные по годам [5, с. 45].

Чтобы увидеть динамику в работе внутренней миссии Владимирской губернии мы взяли статистические данные за каждый год работы миссии и сравнили их. Миссионерская деятельность в Российской империи начала масштабно развиваться после открытия Православного миссионерского общества в 1870 году. Однако во Владимирской губернии деятельность миссии набрала обороты только к концу 1880-х годов.

Данный факт хорошо прослеживается не только по отчетам православных братств и статьям, посвященным деятельности тех или иных священников, но и по статистическим данным, размещавшимся в официальной части Владимирских епархиальных ведомостей (далее ВЕВ).

«Владимирские епархиальные ведомости» - это периодическое печатное издание, публиковавшееся во Владимирской губернии на протяжении пятидесяти четырех лет (1865-1919 гг.), включавшее в себя огромный массив разнообразных актовых, публицистических, нормативных и статистических материалов. В интересующий нас период ведомости выходили два раза в месяц.

ВЕВ делятся на официальную и неофициальную части. В работе мы использовали материалы официальной части, раздела «епархиальные известия». 
Статистические данные, публиковавшиеся в ведомостях, прежде чем попасть на страницы издания, преодолевали длинный путь. Так, в ВЕВ нередко печатались наказы сдавать статистику вовремя (в определенный месяц). Миссионеры, организовывая школы, собеседования, публичные чтения, проводя обряды крещения, отчитывались перед уполномоченным братства (если миссионером не был сам уполномоченный), далее информация направлялась в Совет братства, где обрабатывалась и передавалась в редакцию ведомостей. Данные печатались по мере накопления, но при этом задержка печати не превышала трех месяцев.

До 1889 года сообщений о крещениях в православие в ВЕВ практически нет. Если быть более точным, сообщения встречаются, но в косвенном виде: в форме благодарностей священнику за усердие на миссионерском поприще.

Научная новизна работы определяется формулировкой темы. Мы впервые предприняли попытку статистического анализа миссионерской деятельности православного духовенства Владимирской губернии в конце XIX - начале XX века; ранее никем не предлагались идеи по оценке деятельности внутренней миссии Владимирской губернии на основе статистических данных, публиковавшихся во Владимирских епархиальных ведомостях.

Практическая значимость исследования состоит в возможности использовать материалы, представленные в работе, для написания исследований по истории церкви, межконфессиональных отношений на региональном уровне. Данные, на основе которых писалась работа, могут стать подспорьем при написании генеалогических работ, при изучении жизнедеятельности священно-церковнослужителей.

В ходе изучения результативности внутренней миссии Владимирской губернии, мы собрали значительное количество статистических материалов, которые сгруппировали в статистические таблицы.

Первоначальная таблица с данными о крестившихся и крестивших, о месте проживания, возрасте, сословии, приходе, вероисповедании заняла 81 страницу.

Для удобства мы распределили информацию по 20 таблицам, с которыми и работали. Первые 13 таблиц были сделаны из учета 13 уездов, на которые делилась Владимирская губерния в изучаемый период. Мы распределили священнослужителей по уездам, в которых они служили, а также подсчитали, сколько человек каждый крестил. Сложность заключалась в том, что некоторые священники упоминались в ВЕВ по несколько десятков раз, и это увеличило первоначальный список до тысячи имен. Также оказалось, что некоторые священники упоминались всего один раз, при этом не давалось никакой информации ни о приходе, в котором они служили, ни об уезде. Либо просто указывалась деревня, в которой служил священник без принадлежности к уезду. Тогда нам на помощь пришли Памятные книжки Владимирской губернии, в которых были даны все статистические данные об уездах.

С помощью таблиц мы смогли увидеть, сколько человек в среднем крестил священник за год служения в приходе. Так мы смогли выявить динамику в деятельности внутренней мисси.

Оставшиеся семь таблиц включили данные о конфессиональной принадлежности крестившихся, о месте их проживания (в городе или в уезде), о сословной принадлежности, о поле и возрасте.

При распределении по сословиям мы испытывали некоторые трудности, так как не у всех крестившихся давалось пояснение о сословной принадлежности. Особенно это касалось военных. Большая часть, представленных в ведомостях людей относилась к крестьянству. Но некоторые семьи военных в отставке являлись выходцами из городов западных губерний и принадлежали к мещанам. Но при этом большинство были выходцами с Поволжья, в основном из Казанской губернии и из Сибири.

Мы столкнулись с проблемой, к какой категории относить тех, кто служил в гражданском ведомстве и почетных граждан. Однако уже в изучаемый период их выделяли в особые группы, о чем мы узнали из таблиц, представленных в отчетах о переписи 1897 года. Таблицы еще раз показали численное преобладание крестьянского населения, в сотни раз превышающее все остальные сословия.

Так как мы оказались первопроходцами в подобной работе с материалами ведомостей, мы пользовались вышеуказанной методикой. Однако это не значит, что впоследствии мы не сможем найди более удобный вариант классификации данных о крестившихся в православие, который облегчил бы анализ материалов.

Итак, данные, опубликованные в ВЕВ с марта 1889 года по 1905 год, мы объединили в сводную таблицу «Миссионеры и принявшие православие во Владимирской губернии». Таким образом, период, по которому мы составляли статистику, сократился с тридцати пяти (если считать началом миссионерского служения в губернии 1870-й год) до шестнадцати лет. Но и за такой небольшой промежуток времени прослеживается динамика внутренней миссии, выявляются места наибольшей концентрации миссионеров и старообрядцев.

Мы проанализировали данные работы внутренней миссии в тринадцати уездах Владимирской губернии: Александровском, Владимирском, Вязниковском, Гороховецком, Ковровском, Меленковском, Муромском, Переславском, Покровском, Судогодском, Суздальском, Шуйском и Юрьевецком уездах.

Для каждого уезда миссионерами мы считали тех, кто крестил в православие хотя бы одного человека. Сделаем поправку, что мы в данной статье рассматривали только миссионеров из среды духовенства, тогда как в уезде были также, так называемые начетчики - миссионеры из среды мирян. 
Всего по данным ВЕВ в период с 1889 по 1905 годы мы зафиксировали 421 миссионера, из которых самая большая доля приходится на Владимирский уезд (61 человек) и Шуйский уезд (60 человек). В основном это были сельские священники, служившие в раскольнических приходах, а также священники крупных уездных храмов, в которые стекались самые разные люди.

Большая часть миссионеров крестила за исследованный период одного-двух людей. Однако встречаются священники, крестившие более двадцати человек. Это говорит либо о том, что священник возглавил приход, где проживала большая старообрядческая община, либо он в какой-то период своего служения крестил целую семью. Обычно семьями переходили в православие евреи, которые проживали в основном в таких крупных городах губернии, как Владимир, Иваново-Вознесенск и Шуя, также встречаются записи о крещении католических семейств.

Среди уездов можно выделить три с наибольшим количеством крещеных. Это Покровский уезд - там было крещено 386 человек. За ним идет Шуйский уезд - в нем было крещено 358 человек. Заключает тройку Меленковский уезд, где присоединились к Православной церкви 342 человека.

Больше всего крестил миссионер ореховских фабрик Саввы Морозова Василий Рождественский (105 человек), где раскол, как писал В. Добронравов, находил особенно благоприятную почву, потому что предки нынешних владельцев фабрик покровительствовали ему. Они строили для раскольников молитвенные дома, покупали для них книги и иконы, давали преимущество на фабрике [2, с. 370].

Но согласно отчету всероссийской переписи населения 1897 года, первым по численности старообрядческого населения, а значит и главной территорией для миссии, был Гороховецкий уезд (в нем проживала треть всех старообрядцев губернии), однако в нем по нашим данным было всего пять человек, занимавшихся профессионально миссионерством. То есть, посвятивших свою жизнь полностью этому делу. У духовенства уезда было много опасений по поводу местного населения, которое, как они считали, «по большей части склонно к расколу». Особенно интересной ситуация была в погосте Бережцы. Там, как сообщали ведомости, часто случались пожары, и прихожане сильно обеднели, что заставляло их колебаться в вере [1, 1904, №21, с. 633].

Быть миссионером внутренней миссии для священников зачастую оказывалось непростой задачей. Никто не отменял обязанностей, связанных с отправлением треб, проведением богослужений. Большинство священников также являлись учителями церковно-приходских школ. А многим приходилось размещать такие школы в своем доме. Они заведовали библиотеками, преподавали в духовных учебных заведениях, выполняли обязанности, возложенные братством святого благоверного Александра Невского, членами которого являлись многие священнослужители края. Все это сказывалось на результативности миссии.

Не смотря на то, что основной аудиторией владимирских миссионеров были старообрядцы и сами православные, были случаи крещения из других религий (протестантства, иудаизма, католицизма, а также различных сект). Как показывают собранные нами данные, в тех уездах, где приняло православие не так много человек, заметно религиозное разнообразие, крещеные являлись жителями и гражданами разных стран, входили в различные сословия.

По данным всероссийской переписи населения 1897 года во Владимирской губернии проживало 1515691 человек. В эту цифру входили, как уроженцы Владимирской губернии, так и других губерний, и государств (они составляли около 200 тысяч человек, из них 329 человек - иностранцы) [4, с. VIII].

Большую часть населения Владимирского уезда по данным переписи составляли крестьяне $(90,3 \%)$ и мещане $(6,9 \%)$. Из привилегированных сословий $0,7 \%$ составляли потомственные и личные дворяне [4, c. IX].

Большинство дворян $(89,3 \%)$, купцов $(66,8 \%)$ и мещан $(58,9 \%)$ относилось к городскому населению. Крестьян в городах проживало только 7,8\% от общей массы. Однако при этом крестьяне все равно составляли большинство городского населения $-55,9 \%$. Мещан в городах проживало $32,3 \%, 4,2 \%$ потомственных и личных дворян и 4,3\% почетных граждан и купцов [4, с. IX].

Иностранных подданных во Владимирской губернии проживало 403 человека ${ }^{1}$. Из них 49,9\% проживало в городах. В основном, подданные Великобритании (133 чел.) и Германии (131 чел.) [4, с. IX].

В первые годы, когда стали публиковать статистические сведения о решивших принять православие и миссионерах, крещеных было не так много. В 1889 году - 28 человек, в 1890 году - 80 человек, в 1891 году - 73 человека. Из этого мы можем сделать вывод, что те сотни людей, принявших православие, которых мы занесли в сводную таблицу, появились несколько позже.

Так, с 1892 года количество присоединенных к православной церкви дошло до сотни, и ежегодно составляло не меньше 100 человек. Пик пришелся на 1892 год - 242 человека, 1894 год - 204 человека и 1897 год - 196 человек. С 1905 года мы видим явный спад (113 человек). Возможно, такая ситуация была не только во Владимирской губернии. Интересно, что историки церкви с 1905 года начинают новый и последний период миссионерства в России.

${ }^{1}$ Цифра отличается от данных, приведенных в первом абзаце, так как в первом случае учитывались только иностранцы, постоянно жившие в губернии. - В. К. 
За 16 лет во Владимирской губернии в православие было крещено трудами не одной сотни священнослужителей более двух тысяч человек (2299 человек) различных вероисповеданий, уроженцев, как Владимирской губернии, так и других губерний, и других государств.

Православное и единоверческое население составляло большинство (97,22\%). Старообрядцы и уклоняющиеся от православия составляли 2,52\% (те самые 38 тысяч человек, которые записаны в отчете переписи населения 1897 года, как старообрядческое население губернии). Представителей других вероисповеданий не наберется даже полпроцента [4, с. IX].

Количество крещеных в православие старообрядцев составило две тысячи человек - это лишь 5\% от общего числа старообрядческого населения губернии. Число крещеных из сект молокан и штундистов было невелико 34 человека - все крещения относятся к последним годам исследуемого периода, когда миссия обратила внимание не только на раскол, но и на секты. В отчете съезда миссионеров за 1894 год говорилось, что число приверженцев сект в губернии дошло до 2000 человек и с этим не нужно мириться [1, 1894, №1, с. 20].

Большинство крещеных проживало в деревнях и селах губернии. Но 65 из 2067 человек, перешедших из старообрядчества в православие, проживали в городах. Они, в основном, были приезжими на заработки из других губерний: из Московской и Нижегородской. Встречались выходцы из Симбирской губернии и один раз из Самарской - они оказались во Владимирской губернии при распределении, когда уходили служить в армию. Большинство старообрядцев, проживавших в городах, были крещены в городе Шуя (24 человека) и в ИвановоВознесенске (20 человек).

Большинство крещеных были крестьянами. Более двух тысяч человек проживали в деревнях, селах, слободах и погостах губернии. Мещане идут на втором месте по количеству принявших православие. За исследуемый период из мещанского сословия принял православие 221 человек. При этом около половины мещан являлись уроженцами западных губерний: преимущественно иудеями Могилевской и Виленской губерний.

Купцов и дворян, принявших православие, было не так много, как мещан и, тем более, как крестьян. Всего по 8 человек в каждой категории. Все крещеные проживали в городах. В основном, во Владимире, Шуе, ИвановоВознесенске.

В отчете о проведенной во Владимирской губернии переписи чиновники и почетные граждане выделены в особые сословия. Поэтому мы также решили выделить их в отдельную категорию. Среди чиновников (коллежские асессоры, губернский секретарь, статский советник, коллежский советник) пришло к православию 15 человек.

Почетных граждан решившихся креститься в православие было намного меньше. Наверное, потому что они и так, в большинстве своем были православными. А те, кого крестили, были лютеранами и католиками [1, 1905, №7, c. 154].

Итак, мы обобщили данные о крещеных в православие с 1889 по 1905 годы по местам жительства (город, сельская местность), вероисповеданию (старообрядчество, сектантство) и сословиям (дворяне, купцы, мещане, крестьяне, чиновники, почетные граждане). Среди исследованных нами категорий мы увидели вполне закономерную связь. Большинство крещеных старообрядцев были крестьянами и проживали в сельской местности. В городах их было незначительное количество. Мы знаем, что многие купцы также были старообрядцами, но в ведомостях мы практически не встречались с записями об их крещении. Что касается сект, то они распространялись по промышленным центрам, в основном, все крещенные из штундистов и молокан проживали в городах губернии.

В ВЕВ в статьях, ориентированных на священников, занимавшихся миссионерской деятельностью, нередко упоминалось, что переубедить взрослого, сложившегося человека сложно. К этим людям нужен особый подход. Миссионер должен прекрасно знать все особенности религиозного учения человека, с которым приходилось работать. Его язык должен был быть доступным и убедительным.

Мы распределили всех принявших православие на несколько групп: по половому и возрастному признакам: на мужчин и женщин от 0 до 18; от 19 до 35, от 36 до 59 и от 60 до $90^{2}$ лет. Также, мы посчитали средний возраст принимавших православие. Здесь мы ограничились тремя группами: взрослые (мужчины и женщины) и дети (от 0 до 18). ${ }^{3}$

За исследуемый период во Владимирской губернии приняло православие 2299 человек. Из них 1094 человека - мужчины и 1205 - женщины. Как мы видим, женщин, принявших решение сменить религию, было больше. Дети составляли треть от всех принявших православие (763 человека). Обычно запись о крещение людей младше 18 лет встречается в связи с крещением родителей, либо давалась приписка, что дети крестятся с согласия родителей. Хотя и здесь были исключения. Иногда в ведомостях давался просто список детей разных деревень, крестившихся

${ }^{2}$ В статистических данных, опубликованных во Владимирских епархиальных ведомостях нет упоминаний о людях старше 90 лет, принявших православие. - В. К.

${ }^{3}$ В статистике по половому и возрастному признаку мы не делали разграничений на религиозную принадлежность. Так как миссионеры края не делились по религиям, а крестили всех, то вполне справедливо сделать общую статистику. Тем более, что доля крещеных из неправославных религий незначительна. - В. К. 
в православие, без каких-либо дополнительных сведений об их семьях ${ }^{4}$. Мы предположили, что, всего скорее, это дети из тех семей, где родители либо уже приняли православие, либо уступили детям, учившимся, вероятнее всего, в церковно-приходских школах.

Большинство крестившихся в православие - это люди до 35 лет (1426 человек). И только 115 человек старше 60 лет изменили свое мировоззрение и перешли в православие. Но все же были люди, крестившиеся и в 70 лет, и даже в 90. Среди них немало мужчин.

Мы определили средний возраст, принимавших православие. Для мужчин он составил 34 года. Практически та же цифра у женщин - 33 года. Средний возраст крещеных детей составил 12 лет. Интересно также то, что основная масса крестьян, принявших православие, записана в ведомостях формулировкой «крестьянский сын тойто деревни». Поначалу эта формулировка смущала нас, так как не у всех крестившихся указывался возраст. Можно было подумать, что перед нами ребенок в прямом смысле слова. И иногда оказывалось, что это действительно так, когда к имени добавлялся возраст. Но мы записывали всех, не имевших точных указаний о возрасте в категорию взрослых, чтобы впоследствии не было путаницы.

Подводя итоги нашему исследованию, заметим, что материалы Владимирских епархиальных ведомостей хорошо иллюстрируют деятельность внутренней миссии Владимирской епархии конца XIX - начала XX века. Они позволяют сделать выводы не только о направлениях деятельности миссии, об организациях, действовавших в губернии, но и о людях творивших миссию. Кроме того, есть уникальная возможность подкрепить все сведения статистическими данными, с помощью которых можно увидеть, насколько результативны были труды миссионеров.

Самым интересным открытием для нас стало то, что до нас никто не пробовал составить статистику деятельности миссии на основе данных Владимирских епархиальных ведомостей, впрочем, на основе других епархиальных ведомостей также мы не встретили ни одной работы подобного характера.

Внутренняя миссия во Владимирской губернии зародилась задолго до 1870 года - времени создания Православного миссионерского общества. Но свое развитие и практическое применение она получила даже не в 1870 году, а только во второй половине 1880 -х годов, когда накопленный братствами и миссионерами опыт стал успешно применяться в приходах епархии.

Работа владимирской миссии стала удивительным союзом духовенства и мирян, направленным на борьбу с ростом раскола и сект. Можно только удивляться, сколько самопожертвования, трудов, средств было вложено в общую задачу. Главное, что движение, зародившееся в этот период, не стало бесполезным, как впоследствии писали советские авторы. Ведь, именно в этот период начался рост образования, население получило больше источников для полезного досуга. Нельзя сказать, что прогресс в приобщении к православной традиции отсутствовал. Главным же достижением этого периода стало появление новых, более гуманных форм распространения православия и просвещения. Однако к 1905 году отчетливо просматривается спад в миссионерской деятельности, что в первую очередь отразилось на количестве крещеных в православие.

\section{Библиографический список:}

1. Владимирские епархиальные ведомости // НФ ШКМ.

2. Добронравов В. Историко-статистическое описание церквей и приходов Владимирской епархии. Шуйский и Ковровский уезды, Вязниковский и Гороховецкий уезды. Владимир, 1898. Вып. 5. с. 505.

3. Новая иллюстрированная энциклопедия. Том 11. М., 2006. с. 237. c. 233 .

4. Первая всеобщая перепись населения Российской империи 1897 г. / под ред. Н.А.Тройницкого. СПб., 1904.

5. Преображенский И. Отечественная церковь по статистическим данным с 1840-41 по 1890-91 гг. СПб, 1901. c. 236 .

${ }^{4}$ Большое количество детей, крестившихся в православие, встречается в ведомостях только в случае крещения старообрядческих семей сельской местности и ни разу не встречалось упоминание о старообрядческих семьях, проживающих в городе. - В. К. 